Note: this is a pre-review manuscript currently under

review for publication in Geology. (March 4, 2018)

\title{
1 Is fine sediment in sandy riverbed deposits a proxy for paleo-
}

2 sediment supply?

3 Nathaniel Wysocki ${ }^{1}$ and Elizabeth Hajek ${ }^{1, *}$

$4 \quad{ }^{I}$ Department of Geosciences, Pennsylvania State University, 503 Deike Building, University

5 Park, $P A 16802$

$6 \quad$ *Corresponding Author

7 ABSTRACT

8 The amount of silt and clay supplied to rivers can be a primary control on the form and dynamics

9 of channel networks, and it affects the distribution and interconnectedness of buried fluvial

10 reservoirs. Despite its importance, it is difficult to reconstruct how much fine sediment was

11 supplied to ancient rivers. The presence of silt and clay accumulations in sandy river deposits is

12 often interpreted as an indication of variability in flow conditions due to seasonal stagnation or

13 tidal influence, but it has not been tested whether these deposits can be used to evaluate how

14 much fine sediment was transported in ancient rivers. Here we report results from a series of

15 experiments designed to evaluate how much clay and silt are preserved in sandy riverbed

16 deposits under constant and variable discharge conditions. Our results demonstrate that 1) clay-

17 silt deposits, including drapes and lenses, form under constant high-discharge conditions, 2) the

18 amount of fine sediment recovered from bed-material deposits is higher when more fine

19 sediment is supplied, and 3) the fraction of fine sediment trapped during bed aggradation is

20 higher than what is retained during bypass conditions. These results confirm that fine-sediment

21 accumulations are not unique indicators of variable flow conditions and that the net retention of 
22 clay and silt in sandy riverbed deposits may be more indicative of the overall amount of fine

23 sediment supplied to a river.

24 INTRODUCTION

25 Understanding how clay and silt are deposited and stored in riverbed sediments is

26 important for a range of geologic and river-management issues. In modern rivers, the amount and

27 distribution of fine sediment in riverbeds impacts riverine habitats, contaminant transport and

28 leaching, and engineering decisions (e.g., Downs et al., 2009; Draut and Ritchie, 2015; Hamm et

29 al., 2011; Packman and Brooks, 2001; Wooster et al., 2008). In ancient deposits, the abundance

30 and distribution of mud accumulations control the quality and connectivity of fluvial aquifers

31 and hydrocarbon reservoirs (e.g., Bierkens and Weerts, 1994; Jackson et al., 2005), and are

32 useful for interpreting paleoenvironmental conditions in ancient fluvial systems, including the

33 variability or seasonality of discharge (e.g., Plink-Bjorklund, 2015) and the long-term balance of

34 sediment accumulation relative to river mobility (e.g., Hampson et al., 2012). Additionally, there

35 are important outstanding questions about the influence of clays on channel dynamics (e.g.,

36 Matsubara et al., 2015). The ability to reconstruct the relative abundance of clay supplied to

37 ancient rivers on Earth or other planets would help answer these questions and improve

38 paleoenvironmental reconstructions from sedimentary deposits.

39 Because fine sediment can be transported with relatively low flow velocities and has a

40 slow settling velocity, clay and fine silt accumulations in channel-bed deposits are often

41 interpreted as indicating periods of very low flow or standing water. Consequently, clay drapes

42 and lenses within ancient channel deposits are commonly cited as evidence of tidal influence,

43 seasonal stagnation, or waning flows (e.g., Bhattacharya, 1997; Martin, 2000; Plink-Bjorklund,

44 2015; Steel et al., 2011). However, studies have shown that fine sediment can be incorporated 
45 into porous beds under high discharge conditions (e.g., Baas et al., 2016; Packman and MacKay,

46 2003). This raises the question of how to differentiate fine-sediment accumulations formed under

47 variable or low discharge from those deposited under higher discharge conditions. Furthermore,

48 if fine sediments are routinely incorporated into fluvial bed material under a range of flow

49 conditions, the fraction of fine sediment preserved in ancient fluvial deposits may be useful for

50 reconstructing the proportion of fines supplied to ancient river systems.

51 The presence of fine sediment can significantly influence sediment transport and flow

52 conditions in channels. High clay concentrations can alter the structure of turbulent flows,

53 suppressing turbulence completely when concentrations are high enough, and clay in channel

54 beds can increase the effective shear stress necessary to erode the bed (Baas et al., 2016).

55 Together these effects can change the scale, shape, and migration rate of bedforms, and

56 ultimately may influence the character of sedimentary deposits from flows with high clay loads

57 (e.g., Baas et al., 2011). The stratigraphic manifestation of the effects of clay on bedform

58 morphodynamics is still being evaluated. In particular, for fully turbulent flows, it remains

59 unclear whether differences in supplied clay concentrations in can be recorded in bed-material

60 deposits formed under constant discharge.

61 We conducted a series of experiments to evaluate whether clay deposition occurs in

62 sandy river beds under fully turbulent high-discharge conditions, and whether the amount of clay

63 found in bed deposits is related to the amount of clay supplied to the flow. The experiments were

64 designed to explore whether the amount of fine-sediment supplied to a flow affects the amount

65 and distribution of fine-sediment accumulations in the bed and whether variable flow conditions

66 significantly enhance the amount of fine-sediment deposited and stored in sandy river beds.

\section{EXPERIMENTAL DESIGN}


We performed a series of five experiments in a feed-style flume at the St. Anthony Falls

69 Laboratory (University of Minnesota; Figure 1). Water and sediment discharge were set to

70 aggrade a sand bed via a wedge of sediment that prograded down the flume during each run; this

71 is analogous to a bar with superposed bedforms migrating downstream in a river. Sand

$72\left(\mathrm{D}_{50}=0.343 \mathrm{~mm}\right)$ and kaolin clay $\left(\mathrm{D}_{50}=0.004 \mathrm{~mm}\right)$ were supplied to the flume at a constant rate.

73 A clay slurry, with different concentrations for each run, was added to the flume at a rate of $11 / \mathrm{s}$.

74 Total water discharge for each run was $21 \mathrm{l} / \mathrm{s}$ and was monitored an acoustic Doppler

75 velocimeter (ADV) and by measuring the water depth over the weir at the end of the flume.

76 Water exited the end of the flume over a weir that was fixed, allowing the bed to aggrade during

77 each run. Sand discharge was set at $15.0 \mathrm{~g} / \mathrm{s}$ in all runs. The bed aggraded to the weir elevation in

78 about four hours and each run was continued at bypass for 15 to 30 minutes.

Three runs had constant water discharge but different clay concentrations and one run

80 had variable water discharge (Table). Discharge for all runs was sufficient to transport clay as

81 wash load and the sand was transported in the suspended-load regime, consistent with natural

82 sand bed systems where bed material $\mathrm{D}_{50} \leq 0.50 \mathrm{~mm}$ is often transported in suspension

83 (Wilkerson and Parker, 2011) and all runs were equivalent to the fully turbulent flows of Baas et

84 al. (e.g., 2016). The four constant-discharge runs had clay concentrations of 0.0, 1000, 4000,

$858500 \mathrm{mg} / \mathrm{l}$. The variable-discharge experiment had low clay concentration $(1000 \mathrm{mg} / \mathrm{l})$ and water

86 and sediment discharge were slowed and stopped every hour, allowing fine sediment to settle

87 onto the bed.

88 Each run was recorded from the side of the flume with a video camera and photographs.

89 These images were used to reconstruct bed topography and measure bed aggradation and

90 bedform scale in each run. After each experiment, the bed was dried for two days then 
91 excavated. Fine-sediment accumulations were mapped on photographs of the flume wall and

92 samples were collected from bed deposits that accumulated during the aggradational and bypass

93 phases of the experiment. Sediment samples were wet-sieved to determine the fraction of fine

94 sediment. These values were combined with mapped fines accumulations to compare the amount

95 of clay deposited in the bed throughout each run.

96 Experimental parameters and analyses are detailed in Supplementary Material along with

97 links to videos of each run.

98 RESULTS

99 Fine-sediment accumulations in experimental bed deposits included lenses, drapes, and

100 intercalated (interstitial) fines (Figure 2). Visible clay accumulations were most prominent in

101 deposits from the high-concentration run, with most of the bed showing intercalated fines and

102 numerous bedform-scale lenses and continuous drapes of fine sediment. Interstitial clay was less

103 noticeable in the intermediate-discharge run, but bed deposits contained clay lenses and some

104 continuous clay drapes. Bed deposits from the low-concentration run contained some clay

105 drapes. Discontinuous clay drapes formed in deposits of the variable discharge run.

106 The proportion of clay in bed-material deposits increased with higher clay concentrations

107 (Table). For all but the low-concentration constant-discharge run, the weight percent of clay

108 significantly exceeded what would be expected if clay retention were only due to interstitial clay

109 filling bed pore volume at the same concentration as the flow. Additionally, the aggradational

110 phase showed substantially higher clay retention than the bypass phase in all runs. Bed-deposit

111 samples from the variable-discharge run showed higher clay retention than the constant-

112 discharge run with the same clay concentration.

\section{DISCUSSION}


115 to those typically considered diagnostic of variable flow conditions (e.g., clay drapes and flaser-

116 like bedding). This suggests that the presence of clay drapes and lenses in channel deposits is an

117 insufficient gauge of discharge intermittency or tidal influence in ancient rivers without other 118 compelling evidence. Despite having a relatively low clay concentration, the variable-discharge 119 experiment retained more clay than its constant-discharge counterpart. Clay drapes that formed 120 in the variable-discharge run tended to be discontinuous because of erosion that occurred during 121 re-activation of the bed as discharged increased. This suggest that the character of clay 122 accumulations from truly intermittent flows might be differentiable from those generated in 123 rivers with more constant discharge. However, results of these experiments suggest that the 124 overall flux of fine-sediment through a system may be a dominant control on total fine-sediment 125 retention in sandy riverbeds.

$126 \quad$ Clay in these experiments should have been transported as wash load and had limited 127 interaction with the bed; however fine sediment was routinely deposited and preserved along 128 with sandy bed material. These experiments were run in freshwater with kaolinite clay. Although 129 such conditions are not strongly associated with flocculation, some clay aggregates were 130 observed in each experiment and may have contributed to clay accumulation in the bed 131 (Supplemental Videos). However, the majority of clay moving through the flume was suspended 132 uniformly throughout the water column, so aggregates may not have been the primary source of 133 clay extraction from the flow to the bed. Fine-sediment accumulations were most prevalent on 134 the lee sides of individual bedforms downstream of the sediment wedge (e.g., Figure 2). This 135 pattern contrasts with clay accumulation observed in some experiments where advective 136 pumping and hyporheic exchange cause clay to be incorporated into the upstream side of dunes 
137 (e.g., Packman and MacKay, 2003), and suggests that the presence of the sediment wedge 138 facilitated clay deposition in the experiments.

139 The sediment wedge may have initiated a flow-separation zone at its crest which might 140 have promoted clay deposition in a recirculation zone immediately downstream of the wedge 141 front. The prograding wedge also locally sequestered sand in the flume during the aggradational 142 phase of the expeirment. The lower effective sand flux downstream of the wedge resulted in 143 bedform-migration rates that were $\sim 8$ times slower during the aggradation phase $(1.1-1.8 \mathrm{~cm} / \mathrm{s})$ 144 than the bypass phase $(8.6-12.0 \mathrm{~cm} / \mathrm{s})$. Although the concentration of clay supplied to the flow 145 was constant throughout the runs, downstream of the wedge the concentration of clay relative to 146 sand was much higher in the aggradational phase than the bypass phase. Enhanced fine-sediment 147 deposition downstream of the sediment wedge is consistent with field data showing silt and clay 148 accumulations downstream of bars in modern rivers and ancient deposits (Hajek et al., 2011; 149 Lynds and Hajek, 2006).

150 The preservation of accumulated fine sediment (and bed material in general) was likely 151 enhanced by an abrupt increase in local aggradation as the sediment wedge passed a given 152 location in the flume. In field-scale systems bar progradation might rapidly bury slower-moving 153 bedforms, thereby preserving them entirely. This contrasts the partial preservation of relatively 154 fast-moving bedforms (i.e. the lowermost portion of some bedforms are preserved) due to 155 stochastic variation in dune height (e.g., Paola and Borgman, 1991) or slow long-term 156 aggradation (e.g., Leclair, 2002). Collectively, the results of our experiments suggest that, at field 157 scales, morphodynamics of larger features like bars may play a significant role in controlling the 158 deposition and preservation fine sediment and bed material in rivers. 
These results have important implications for interpreting ancient fluvial deposits. First,

160 the fraction of fine sediment preserved in ancient bed-material deposits may reflect the amount

161 of fine sediment supplied to a watershed. This means that relative differences in the proportion of

162 fine sediment within channel-bed sandstones may be useful for determining which ancient fluvial

163 systems had particularly mud-prone sediment sources, especially when coupled with

164 observations about the abundance, geometry, and preservation of reach-scale fine-sediment

165 deposits like inter-bar mudstones and floodplain deposits (e.g., Lynds and Hajek, 2006). This

166 information may be useful for testing hypotheses about relative cohesion among ancient systems

167 and the relationship between clay supply and fluvial planform (e.g., van Dijk et al., 2013).

168 Furthermore, constraining the fraction of fines present bed-material deposits will be helpful for

169 more accurately predicting heterogeneity and compartmentalization in fluvial reservoirs. More

170 work is needed to determine whether quantitative paleosediment-flux reconstructions could be

171 achieved, but in the near term, these results indicate that the amount of silt and clay preserved in

172 riverbed deposits may be sufficient for relative comparisons among ancient rivers and testing

173 hypotheses about which systems had high vs. low clay and silt supplies.

\section{CONCLUSIONS}

175 Results of these experiments demonstrate that 1) low discharge is not a necessary 176 condition for clay deposition in active river beds, 2) clay deposition increases with clay supply, 177 and 3) clay retention in the bed is significantly higher during periods of bed aggradation than 178 sediment bypass, particularly when aggradation is facilitated by bar migration. While variable 179 discharge may enhance clay deposition for a given fine-sediment flux, our results show that 180 significant fine-sediment accumulations in ancient channel deposits may primarily reflect 181 supplied wash load rather than highly variable discharge, as is often interpreted. This indicates 
182 that interpreting high discharge variability, for example tidally influenced flows or seasonal

183 stagnation, requires evidence beyond clay deposits. Our results suggest that the presence of

184 migrating bar forms may facilitate clay deposition and preservation during high flow conditions.

185 Measuring the concentration of clay in ancient river-bed deposits may provide an important

186 avenue for reconstructing paleo-sediment supply, particularly the relative abundance of clays and

187 silts transported by a system; this is a critical variable necessary for understanding past changes

188 in source material or weathering rates and evaluating the how clay contributed to cohesion on

189 ancient landscapes and on other planets.

190 APPENDIX

191 Supplemental data submitted.

192 ACKNOWLEDGMENTS

193 Support for this research was provided by the donors of the American Chemical Society

194 Petroleum Research Fund, NSF Award \#1455240, and student support from the Geological

195 Society of America, American Association of Petroleum Geologists, and Penn State Geosciences

196 to N.W. Without the incredible expertise and generosity of SAFL personnel, particularly Ben

197 Erickson and Sara Mielke this work would not have been possible. We are grateful to E.

198 Chamberlin and Macalester College students for helping run the experiments and thank C. Paola,

199 R. Slingerland, T. Bralower, R. DiBiase, E. Greenberg, and S. Trampush for helpful discussions, 200 and J. Pizzuto and M. Perillo for thoughtful and constructive reviews.

\section{REFERENCES CITED}

202 Baas, J. H., Best, J. L., and Peakall, J., 2011, Depositional processes, bedform development and hybrid bed formation in rapidly decelerated cohesive (mud-sand) sediment flows: Sedimentology, v. 58, p. 1953-1987.

Baas, J. H., Best, J. L., and Peakall, J., 2016, Predicting bedforms and primary current stratification in cohesive mixtures of mud and sand: Journal of the Geological Society of London, v. 173, p. 12-45. 
Bhattacharya, A., 1997, On the origin of non-tidal flaser bedding in point bar deposits of the river Ajay, Bihar and West Bengal, NE India: Sedimentology, v. 44, p. 973-975.

Bierkens, M. F. P., and Weerts, H. J. T., 1994, Block hydraulic conductivity of cross-bedded fluvial sediments: Water Resources Research, v. 30, no. 10, p. 2665-2678.

Downs, P. W., Cui, Y., Wooster, J. K., Dusterhoff, S. R., and Booth, D. B., 2009, Managing reservoir sediment release in dam removal projects: An approach informed by physical and numerical modelling of non-cohesive sediment: International Journal of River Basin Management, v. 7, no. 4, p. 433-452.

Draut, A. E., and Ritchie, A. C., 2015, Sedimentology of new fluvial deposits on the Elwha River, Washington, USA, formed during large-scale dam removal: River Research and Applications, v. 31, p. 42-61.

Hajek, E. A., Lynds, R., and Huzurbazar, S., Comparing particle-size distributions in modern and ancient sand-bed rivers, in Proceedings AGU Fall Meeting, San Francisco, 2011, American Geophysical Union.

Hamm, N. T., Dade, W. B., and Renshaw, C. E., 2011, Fine particle deposition to porous beds: Water Resources Research, v. 47, no. 11, p. n/a-n/a.

Hampson, G. J., Royhan Gani, M., Sahoo, H., Rittersbacher, A., Irfan, N., Ranson, A., Jewell, T. O., Gani, N. D. S., Howell, J. A., Buckley, S. J., and Bracken, B., 2012, Controls on large-scale patterns of fluvial sandbody distribution in alluvial to coastal plain strata; Upper Cretaceous Blackhawk Formation, Wasatch Plateau, central Utah, USA: Sedimentology, v. 59, no. 7, p. 2226-2258.

Jackson, M. D., Yoshida, S., Muggeridge, A. H., and Johnson, H. D., 2005, Three-dimensional reservoir characterization and flow simulation of heterolithic tidal sandstones: AAPG Bulletin, v. 89, no. 4, p. 507-528.

Leclair, S., 2002, Preservation of cross-strata due to the migration of subaqueous dunes: an experimental investigation: Sedimentology, v. 49, p. 1157-1180.

Lynds, R., and Hajek, E., 2006, Conceptual model for predicting mudstone dimensions in sandy braided-river reservoirs: AAPG Bulletin, v. 90, no. 8, p. 1273-1288.

Martin, A. J., 2000, Flaser and wavy bedding in ephemeral streams: a modern and ancient example: Sedimentary Geology, v. 136, p. 1-5.

Matsubara, Y., Howard, A. D., Burr, D. M., Williams, R. M. E., Dietrich, W. E., and Moore, J. M., 2015, River meandering on Earth and Mars: A comparative study of Aeolis Dorsa meanders, Mars and possible terrestrial analogs of the Usuktuk River, AK, and the Quinn River, NV: Geomophology, v. 240, p. 102-120.

Packman, A. I., and Brooks, N. H., 2001, Hyporheic exchange of solutes and colloids with moving bed forms: Water Resources Research, v. 37, no. 10, p. 2591-2605.

Packman, A. I., and MacKay, J. S., 2003, Interplay of stream-subsurface exchange, clay particle deposition, and streambed evolution: Water Resources Research, v. 39, no. 4.

Paola, C., and Borgman, L. E., 1991, Reconstructing random topography from preserved stratification: Sedimentology, v. 38, no. 4, p. 553-565.

Plink-Bjorklund, P., 2015, Morphodynamics of rivers strongly affected by monsoon precipitation: Review of depositional style and forcing factors: Sedimentary Geology, v. 323, p. 110-147.

Steel, R. J., Plink-Bjorklund, P., and Aschoff, J., 2011, Tidal deposits of the Campanian Western Interior Seaway, Wyoming, Utah and Colorado, USA, in Davis, R. A. J., and Dalrymple, R. W., eds., Principles of Tidal Sedimentology: Netherlands, Springer, p. 437-471. 
van Dijk, W. M., van de Lageweg, W. I., and Kleinhans, M. G., 2013, Formation of a cohesive floodplain in a dynamic experimental meandering river: Earth Surface Processes and Landforms, v. 38, no. 13, p. n/a-n/a. describing bankfull hydraulic geometry of sand-bed rivers: Journal of Hydraulic Engineering, v. 137, no. 7, p. 739-753.

Wooster, J. K., Dusterhoff, S. R., Cui, Y., Sklar, L. S., Dietrich, W. E., and Malko, M., 2008, Sediment supply and relative size distribution effects on fine sediment infiltration into immobile gravels: Water Resources Research, v. 44, no. 3, p. n/a-n/a.

FIGURE CAPTIONS

Figure 1. A) Diagram of experimental setup showing flume extent and the location of clay and sand delivery; water entered the flume on the left side and exited over the weir on the right side. Sand was supplied dry and clay was delivered from a mixing tank at different concentrations in each run at a rate of 1 1/s. Data reported here come from the active bed region. The measurement cart included sediment-sampling and ADV equipment (at $2.9 \mathrm{~m}$ ) and videos and photographs were taken from through the sidewall of the flume at $3.25 \mathrm{~m}$. B) Example of bed evolution in the

271 Test Section of the flume during the Intermediate Concentration run (3x vertical exaggertation).

272 Lines show bed topography every 30 minutes through the experiment (progressing from light

273 green to dark green). Raw panel shows the full bed topography and the smoothed panel shows

274 the same data averaged with a moving window of two average bedform lengths $(50 \mathrm{~cm})$. Arrows

275 indicate the approximate position of the front of the sediment wedge at each time. All runs

276 showed the same bed evolution; complete bed-evolution histories and experimental details are

277 included in the supplemental material.

278 Figure 2. Example clay-deposit types found in experimental beds. Striped region defines the pre279 run bed and the dashed line shows the transition from aggradation-phase deposits (below) to 280 bypass-phase deposits (above). The high-concentration, constant-discharge run (A) had the 281 largest visible clay deposits in the form of lenses and abundant continuous clay drapes. The 
282 intermediate-concentration run (B) had smaller, less predominant clay lenses and continuous clay 283 drapes. The low-concentration run (C) lacked clay lenses and had thin clay drapes. The variable284 discharge run (D) showed more prominent clay drapes than its constant-discharge counterpart 285 (C), but drapes were relatively discontinuous compared to those observed in other constant286 discharge runs. All runs also contained intercalated, interstitial clay that was distributed 287 throughout the bed.

288 Table. Summary of experimental bed deposit characteristics. Fine-sediment concentration is the 289 concentration of clay in the flow during each run. Fine sediment deposits describe the dominant 290 types of fine-sediment accumulations mapped in each experimental bed (Figure 2). Expected 291 weight percent of fine sediment in the bed samples is the amount of interstitial clay expected in 292 bed pore waters given the supplied concentration for each run. Aggradation and bypass fine 293 sediment weight percent are the average of samples from each phase of each run. Full bed maps 294 and sample data are included in the supplemental material, along with details of a constant295 discharge control run that contained no supplied clay.

$296{ }^{1}$ GSA Data Repository item 201Xxxx, supplementary data including details of experimental 297 conditions and analyses, is available online at www.geosociety.org/pubs/ft20XX.htm, or on 298 request from editing@geosociety.org or Documents Secretary, GSA, P.O. Box 9140, Boulder, 299 CO 80301, USA. 

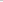


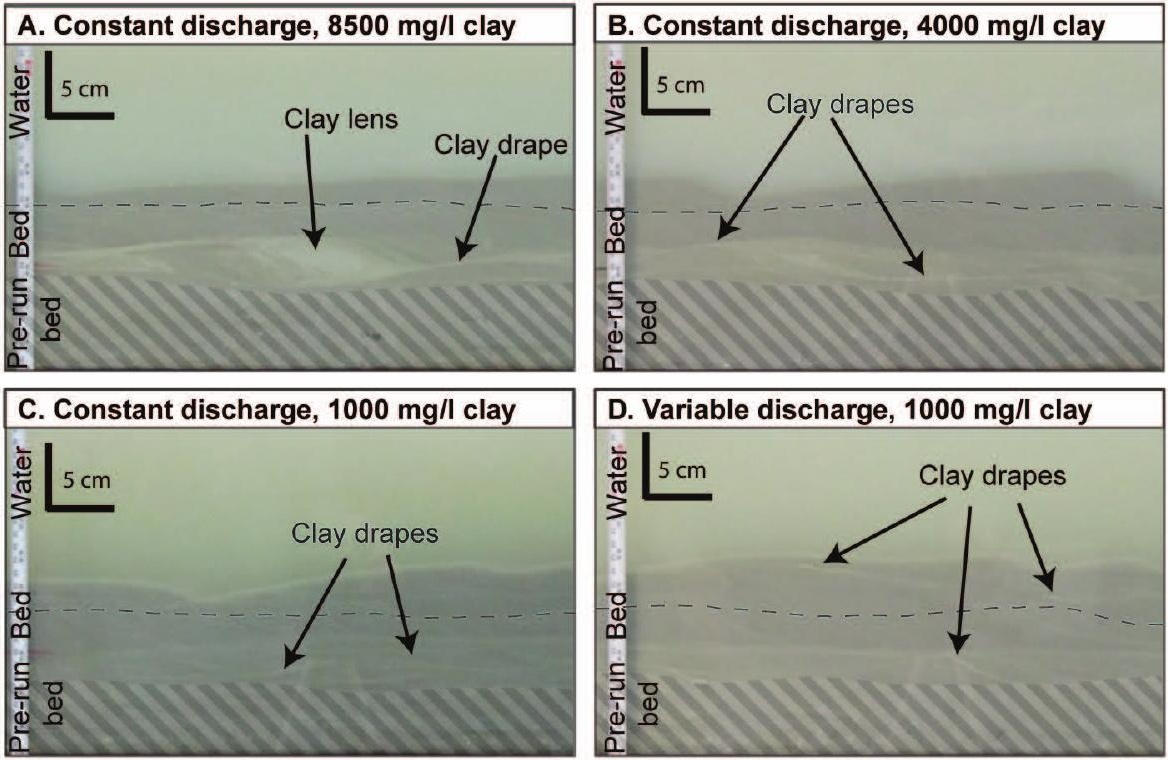




\begin{tabular}{|c|c|c|c|c|c|}
\hline & \multirow{2}{*}{$\begin{array}{l}\text { Fine-sediment } \\
\text { concentration }\end{array}$} & \multirow{2}{*}{$\begin{array}{l}\text { Fine-s ediment } \\
\text { deposits }\end{array}$} & \multicolumn{3}{|c|}{ Fines in bed samples [wt\%] } \\
\hline & & & Expected & Aggradation & Bypass \\
\hline $\begin{array}{c}\text { Low } \\
\text { concentration }\end{array}$ & $1000 \mathrm{mg} / 1$ & Intercalated fines & 0.02 & 0.06 & 0.05 \\
\hline $\begin{array}{l}\text { Intermediate } \\
\text { concentration }\end{array}$ & $4000 \mathrm{mg} / 1$ & $\begin{array}{c}\text { Drapes, intercalated } \\
\text { fines }\end{array}$ & 0.08 & 0.8 & 0.2 \\
\hline $\begin{array}{c}\text { High } \\
\text { concentration }\end{array}$ & $8500 \mathrm{mg} / 1$ & $\begin{array}{l}\text { Drapes, lenses, } \\
\text { intercalated fines }\end{array}$ & 0.17 & 2.2 & 0.4 \\
\hline $\begin{array}{l}\text { Variable } \\
\text { dishcharge }\end{array}$ & $1000 \mathrm{mg} / 1$ & $\begin{array}{c}\text { Disctoninuous drapes, } \\
\text { intercalated fines }\end{array}$ & 0.02 & 0.2 & 0.1 \\
\hline
\end{tabular}




\section{Data repository and supplemental information for Wysocki and Hajek: Is fine sediment in sandy riverbed deposits a proxy for paleo-sediment supply?}

DESCRIPTION OF EXPERIMENTAL PROCEDURES:

Description of flume and sediment used in experiments 2

Startup and shutdown procedures 2

LINKS TO VIDEOS OF EACH EXPERIMENTAL RUN

EXPERIMENTAL CONDITIONS AND BED EVOLUTION: $\quad 5$

Table DR1: Summary of experimental conditions and bed evolution for each run. 5

Table DR2: Run and stop (settling) times for the Variable Discharge run $\quad 5$

Figure DR1: Bed aggradation throughout each run. $\quad 6$

Figure DR2: Histogram of measured bedform heights for each run. 6

Experimental sediment-transport conditions $\quad 7$

Figure DR3: Shield's diagram (after Wilkerson and Parker (2011)) showing experimental sediment-

transport conditions.

$\begin{array}{ll}\text { Fine sediment transport } & 7\end{array}$

Comparison with of experimental conditions with other flume experiments $\quad 8$

Table DR3: Comparison of conditions in this experiment with other mixed sand-clay flume experiments.

Figure DR4: Comparison of flow conditions in experiments from this study to the phase diagram

presented in Baas et al. (2009). 9

Figure DR5: Comparison of experiments in this study to the clay flow phase diagram of Baas et al.

(2009). $\quad 9$

Figure DR6: Topographic profiles through time of each experiment. $\quad 10$

Figure DR7: Turbulence intensity calculated from ADV data from each run. 11

Figure DR8: Suspended sediment concentration profiles. 12

Figure DR9: Example images of clay aggregates in experimental runs. 12

DEPOSIT CHARACTERISTICS AND CLAY ACCUMULATIONS: 13

Table DR4: Experimental deposit characteristics and clay-mapping results. 13

BED DEPOSIT SAMPLING

Table DR5: Bed-deposit sample locations and weight percent of clay in the sample. 14

Bed Deposit Mapping Description and Images 15

Figure DR10: Photographs and mapped clay accumulations of each run as seen through the glass

wall of the flume. 15

REFERENCES $\quad 18$ 


\section{DESCRIPTION OF EXPERIMENTAL PROCEDURES:}

\section{Description of flume and sediment used in experiments}

Experiments were conducted in the 24-in general purpose flume at the St. Anthony Falls Laboratory, University of Minnesota (http://www.safl.umn.edu/facilities/general-purposeflumes-6-inch-20-inch-24-inch-flumes); see Figure 1 in the main manuscript. The flume is a feed style flume 15.42 meters long ( $50 \mathrm{ft}$ ) and $39.97 \mathrm{~cm}$ deep (15.5 in). Near the head box the flume is $61 \mathrm{~cm}$ and between 14.7 and $12.2 \mathrm{~m}$, the flume narrowed from $61 \mathrm{~cm}$ to $30.5 \mathrm{~cm}$. The flume was $30.5 \mathrm{~cm}$-wide for from $12.2 \mathrm{~m}$ to the end $(0 \mathrm{~m})$ at the weir. The weir height for all runs was fixed at $16 \mathrm{~cm}$. For each run, the initial sediment wedge extended from the outlet of the flume to $8 \mathrm{~m}$ and was graded to a slope of 0.004 .

The sand feeder was positioned at $8.5 \mathrm{~m}$ and the sand feed rate was set at $15.0 \mathrm{~g} / \mathrm{s}$ (a voltage of 356 on the auger box). This feed rate was verified before each run and prior to sand feed being turned off at the conclusion of each run. Based on water velocity and fall velocity of the median grain diameter sand $(0.323 \mathrm{~mm})$ the sand traveled $1.5-1.75 \mathrm{~m}$ before reaching the bed. The sand used in these experiments is AGSCO \#40-\#70 silica sand. This has a narrow distribution with $\mathrm{D}_{50}=0.323 \mathrm{~mm}$, and a sorting coefficient of 1.2. A board was positioned below the feeder to disperse the sand supply, spreading it across the width of the flume.

Clay was delivered to the flume via two mixing tanks. First, clay was fully mixed and wetted in a mixing tank located on the floor above the flume. A clay slurry left this initial mixing tank and was delivered to a second $1 \mathrm{~m}^{3}$ mixing tank positioned just above the flume at $12.5 \mathrm{~m}$. In the second mixing tank, the clay slurry was diluted with city water supplied at a rate of $1 \mathrm{l} / \mathrm{s}$ and was mixed via propeller. The dilute clay mixture from the secondary mixing tank was then introduced to the flume at a rate of $1 \mathrm{l} / \mathrm{s}$. Clay was added to the initial mixing tank in volumes that produced the desired final concentration, and the clay slurry was delivered to the secondary mixing tank at a rate to balance the $1 \mathrm{l} / \mathrm{s}$ discharge from the secondary mixing tank into the flume. The water level in the tank and sediment feed rate (especially when high) were variable and were monitored and adjusted frequently throughout the course of each run to maintain the appropriate clay concentration in the flume. The clay feed from the secondary take was run over a board to disperse the clay supply uniformly across the width of the flume; this also helped prevent the slurry from becoming a density flow. Clay used in this experiment was Cary Snobrite kaolin clay with a median grain diameter of $0.004 \mathrm{~mm}$. There was no overlap between sand and clay grain size distributions.

The main water supply to the flume Mississippi River water sourced from the St Anthony Falls Lab main channel diversion.

\section{Startup and shutdown procedures}

$\underline{\text { Start-up checklist }}$

- Set initial sediment wedge by scraping off all sediments from prior experiments and grading the slope at 0.004 .

- Test sand and clay sediment feed rates.

- Wet sediment wedge for over an hour so that water fills all pore spaces. Using a very low discharge, slowly fill the flume to the level of the weir.

- Start camera.

- Increase the flow to the desired discharge. Lift up on hydraulic pump until plate is at correct location (marked). 
- Start clay slurry feed.

$\circ$ Turn on hose and sediment feeder in secondary clay mixing tank.

- Turn on sand feed. This starts the official time.

- Note: Ideally clay and sand are turned on at the same time. This can be done with more than one person. The person downstairs turns the hose on, the person upstairs turns the clay feeder on then opens the ball valve. When the slurry enters the flume, the person downstairs turns on the sand feed.

- Check discharge by the water level going over the weir. Should be at $29 \mathrm{~cm}$. if not, adjust discharge with hydraulic pump.

$\underline{\text { Shut down procedures }}$

- Note time when sediment wedge reaches the weir and the entire bed is at bypass.

- Continue run for 15-30 minutes after this time and begin shut-down.

- Slightly decrease discharge so sand is no longer in suspended load regime.

- Turn off sand feed.

- Turn off clay feed.

- Shut ball valve, turn off hose, turn off sediment feeder.

- Immediately turn off river water discharge.

- Open drain on the headbox so the flume slowly drains from both sides.

- When bed is drained (still water in the flume, just not above the bed surface) open drain on headbox fully to allow flume to fully drain.

- Turn fan on the bed. Fan is attached to the top of the flume with clips at 1.5 meters blowing upstream.

- $\quad$ Let bed dry over two nights.

Procedures during run

- Collect velocity measurements at 6/10 water depth for 5-10 minutes.

- Collect additional velocity profiles by measuring for one minute at increments of $2 \mathrm{~cm}$ water depth from the bed to the top of the flow. (This proved difficult with migrating bedforms.)

- Collect bed and water surface elevation measurements from measuring tape every $50 \mathrm{~cm}$ of the test section. Make water surface elevation measurements every 1 meter outside of the test section.

- Take photographs of the test section every 30 minutes (15 minutes after bed and water surface elevations).

$\circ$ These are taken $180 \mathrm{~cm}(\sim 6 \mathrm{ft})$ away from the flume at points (for the left foot of the tripod) marked on a piece of tape on the floor.

- Suspended sediment samples

- Samples are taken every 30 minutes by a rake of suspended sediment samplers (Photo), with active tubes spaced $5 \mathrm{~cm}$ apart.

Photo: Suspended sediment sampler

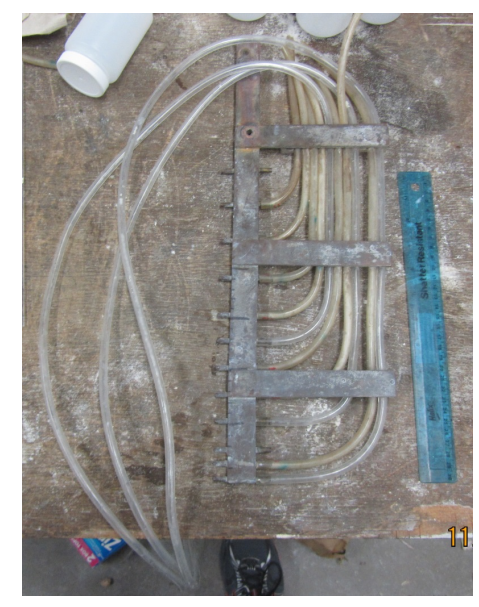

- Suspended sediment sample are collected at the $2 \mathrm{~m}$ position in the flume from $3 \mathrm{~cm}, 8$ $\mathrm{cm}$, and $13 \mathrm{~cm}$ above the bed.

- Samples are taken by siphoning water through tubes and letting water enter $16 \mathrm{oz}$ containers 
- Nearest dune location and dune height are noted

- Active bed material samples

- Grab samples are taken every 30 minutes (with suspended sediment samples) taken with $8 \mathrm{oz}$ containers.

- Taken from top few centimeters of closest upstream dune to the $2 \mathrm{~m}$ position in the flume.

- Note the time when the prograding wedge reaches the weir and the entire bed is at bypass.

- Continue run for 15- 30 minutes.

Shutdown and startup procedures for variable flow run

- Follow shut-down procedures as normal with the exception of only turning down the clay feed before turning the river water off. Immediately after river water is turned off, shut down clayfeed and let the bed slowly drain naturally. Do not open the valve in the headbox.

- Allow clay to settle for prescribed time.

- To start flume, turn on clay feed to a very low discharge and slowly increase river water discharge (so as not to send a flood wave through the flume eroding the bed). When river discharge is up, turn on clay and sand feed as normal.

\section{LINKS TO VIDEOS OF EACH EXPERIMENTAL RUN}

\section{High Concentration Run:}

https://www.youtube.com/watch?v=94093QsWivU

https://www.youtube.com/watch?v= hLRHIdaPxI

Intermediate Concentration Run:

https://www.youtube.com/watch?v=wtui5OUFGvw

https://www.youtube.com/watch?v=nTdUC845o8Y

Low Concentration Run:

https://www.youtube.com/watch?v=-fE8 mEmQ0Q

Variable Discharge Run:

https://www.youtube.com/watch? $\mathrm{v}=\mathrm{N} 4 \mathrm{nBBHzqulE}$

https://www.youtube.com/watch?v=XZfngqdCwZ8 


\section{EXPERIMENTAL CONDITIONS AND BED EVOLUTION:}

Table DR1: Summary of experimental conditions and bed evolution for each run.

Aggradation time is the total time the experiment experienced a net increase in average bed elevation in the test section (starting from the beginning of the experiment) and bypass time is the total time the experiment was run after the bed in the test section fully aggraded (i.e. no net increase in mean bed elevation).

\begin{tabular}{|c|c|c|c|c|c|}
\hline & No Fines & $\begin{array}{c}\text { Low } \\
\text { Concentration } \\
\end{array}$ & $\begin{array}{c}\text { Intermediate } \\
\text { Concentration } \\
\end{array}$ & $\begin{array}{c}\text { High } \\
\text { Concentration } \\
\end{array}$ & $\begin{array}{c}\text { Variable } \\
\text { Discharge } \\
\end{array}$ \\
\hline \multicolumn{6}{|c|}{ EXPERIMENTAL CONDITIONS } \\
\hline Water discharge $(1 / \mathbf{s})$ & 21 & 21 & 21 & 21 & $\begin{array}{c}\text { Variable } \\
\text { (see Table DR2) }\end{array}$ \\
\hline Sand discharge $(\mathrm{g} / \mathrm{s})$ & 15.0 & 15.0 & 15.0 & 15.0 & $\begin{array}{l}15.0 \text { (when water } \\
\text { discharge }>0 \text { ) }\end{array}$ \\
\hline $\begin{array}{l}\text { Clay concentration } \\
(\mathrm{mg} / \mathrm{l})\end{array}$ & 0 & 1,000 & 4,000 & 8,500 & 1,000 \\
\hline Total run time (min) & 303 & 272 & 277 & 253 & 262 \\
\hline $\begin{array}{l}\text { Aggradation time } \\
\text { (min) }\end{array}$ & 239 & 239 & 262 & 236 & 247 \\
\hline Bypass time (min) & 64 & 33 & 15 & 17 & 15 \\
\hline \multicolumn{6}{|c|}{ BED EVOLUTION } \\
\hline $\begin{array}{l}\text { Bed aggradation rate } \\
(\mathrm{cm} / \mathrm{min})\end{array}$ & 0.024 & 0.025 & 0.025 & 0.025 & 0.024 \\
\hline $\begin{array}{l}\text { Total bed } \\
\text { aggradation (cm) }\end{array}$ & 6.1 & 6.1 & 6.8 & 6.4 & 6.6 \\
\hline $\begin{array}{l}\text { Downstream wedge } \\
\text { progradation rate } \\
(\mathrm{cm} / \mathrm{s})\end{array}$ & 2.4 & 2.4 & 2.1 & 2.8 & 2.1 \\
\hline $\begin{array}{l}\text { Mean bedform height } \\
\text { (cm) }\end{array}$ & 2.3 & 2.5 & 2.2 & 2.3 & 2.2 \\
\hline $\begin{array}{l}\text { Bedform height } \\
\text { standard deviation } \\
\text { Mean bedform } \\
\text { migration rate }(\mathrm{cm} / \mathrm{s})\end{array}$ & 1.5 & 1.4 & 1.4 & 1.2 & 1.2 \\
\hline Aggradational Phase & --- & 1.1 & 1.1 & 1.8 & 1.2 \\
\hline Bypass Phase & --- & 12.0 & 8.6 & 11.1 & 10.2 \\
\hline
\end{tabular}

Table DR2: Run and stop (settling) times for the Variable Discharge run

Run time (min)

Settling time (min)

\section{Part 1}

59

69

Part 2
55

69
Part 3

56

1010

Part 4
66
179

179
Part 5

27

End of run 
Figure DR1: Bed aggradation throughout each run.

Bed elevation is the mean elevation of the bed (e.g., mapped profiles in Manuscript Figure 1 and Figure DR6). High = High Concentration Run, Int $=$ Intermediate Concentration Run, Low = Low Concentration Run, Var = Variable Concentration Run, $\mathrm{Nf}=$ No Fines (control) Run.

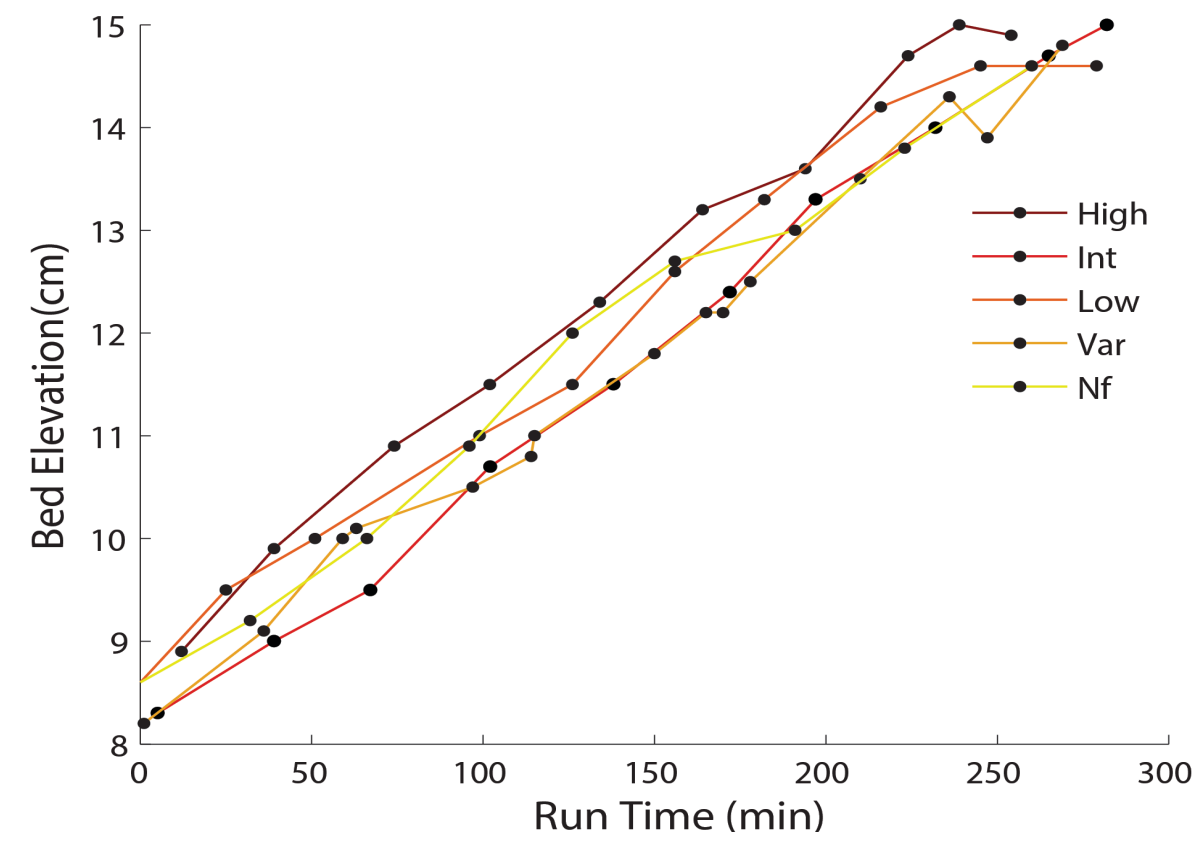

Figure DR2: Histogram of measured bedform heights for each run.

On bed-topography profiles mapped from photos every 30 mins throughout the experiment (Figure DR4), the height (elevation of crest minus elevation of trough) and length (distance between dune crests) of each bedform was measured. Number of bedforms measured for each experiment: No Fines $(\mathrm{NF})=188$, Low Concentration $(\mathrm{Low})=202$, Intermediate Concentration $($ Int $)=246$, High Concentration $($ High $)=214$, Variable flow $($ Var $)=420$.

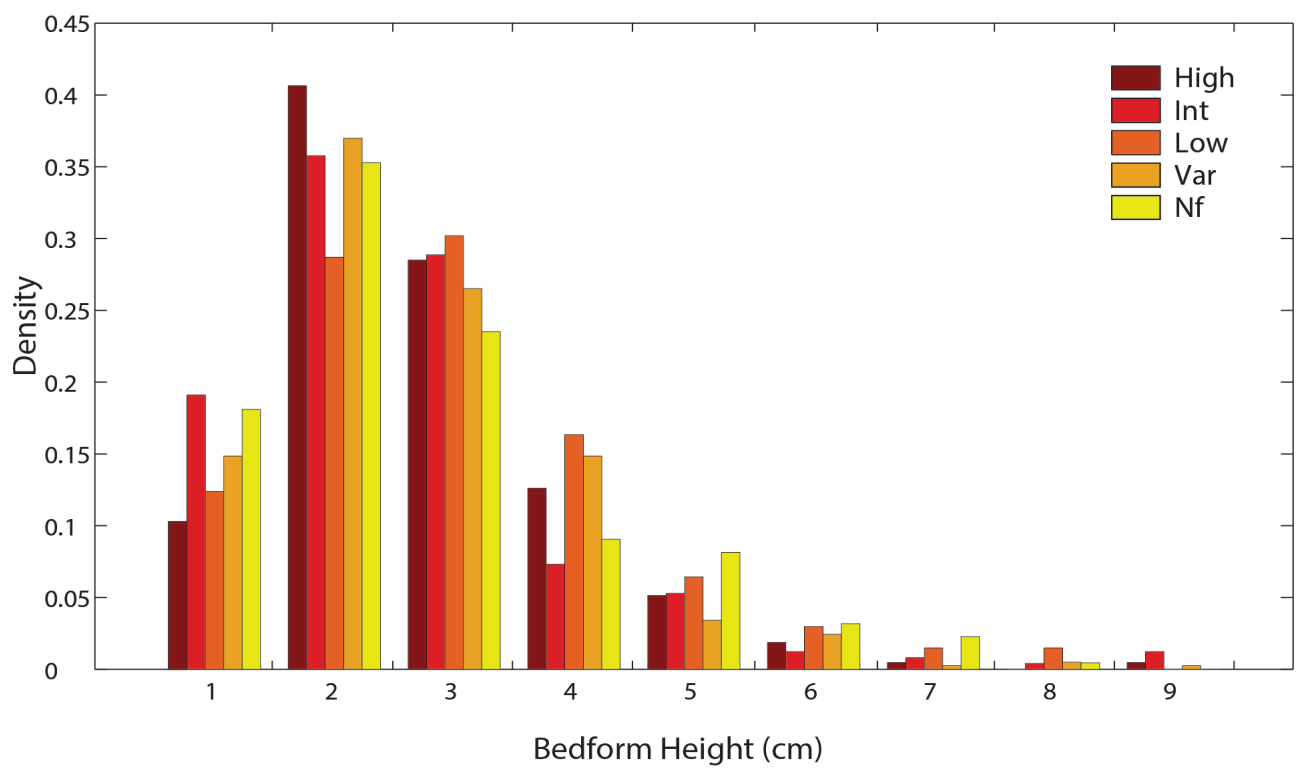




\section{Experimental sediment-transport conditions}

Figure DR3: Shield's diagram (after Wilkerson and Parker (2011)) showing experimental sediment-transport conditions.

Shields Stress $\left(\tau_{b f}^{*}\right)$ was calculated using Wilkerson and Parker's Equation 13:

$$
\tau_{b f}^{*}=\frac{H_{b f} S}{R D_{50}}
$$

where $H_{b f}$ is the flow depth, $S$ is the slope, $R$ is the submerged specific gravity of sediment, and $D_{50}$ is the median grain size.

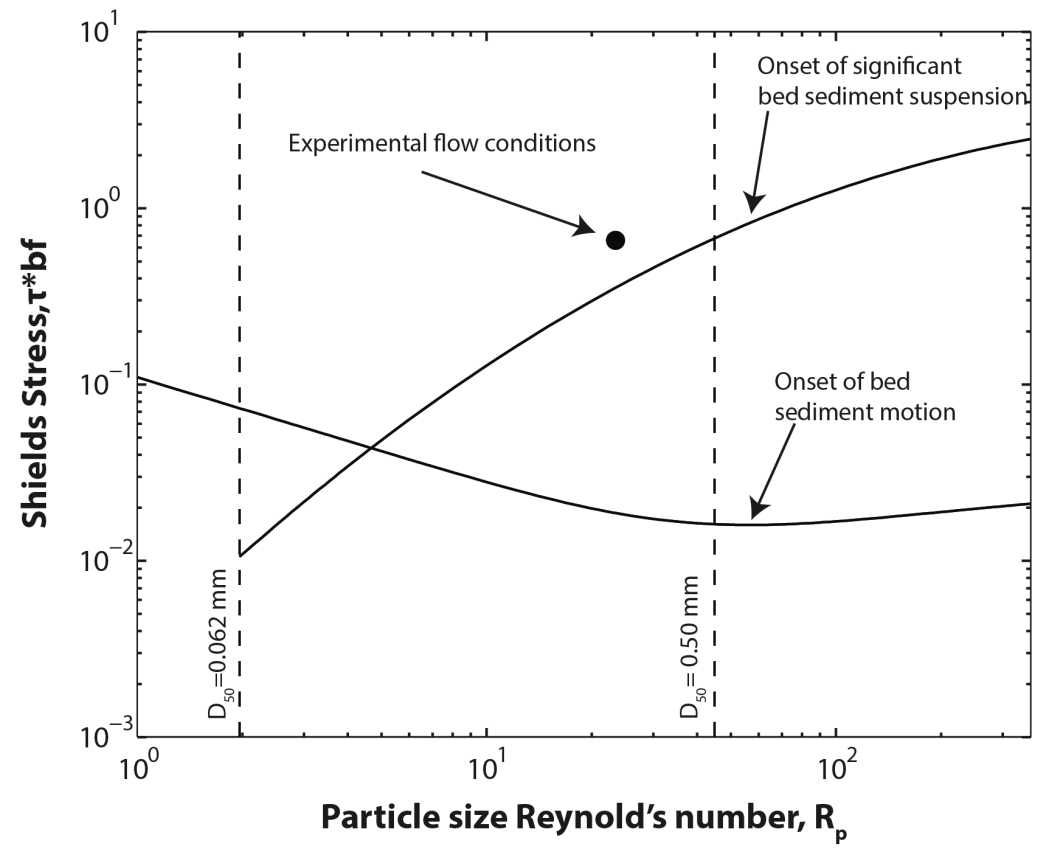

\section{Fine sediment transport}

Fine sediment supplied to the flume should have bypassed the entire flume as wash load. Given the slowest average water discharge in the suite of experiments $(40 \mathrm{~cm} / \mathrm{s})$, and a settling velocity for clay in freshwater of $0.0002 \mathrm{~cm} / \mathrm{s}$ (Sutherland et al., 2015), clay introduced at $12.5 \mathrm{~m}$ in the flume would have settled only 60 microns through the water column during its transport downstream in the experiments. Additionally, the concentration of clay in these experiments $(0.5 \%$ by weight) was lower than the concentrations shown to induce significant changes in settling behavior of clay (either through flocculation or hindered settling, e.g., Sutherland et al., 2015) or the turbulence character of the flow (e.g., Baas et al., 2009). 


\section{Comparison with of experimental conditions with other flume experiments}

\section{Table DR3: Comparison of conditions in this study with other mixed sand-clay flume experiments.}

Values for experiments in this study are averages of measurements taken throughout each run. Concentration (C) was imposed in each run. Flow depth (h) for each run is the average watersurface elevation minus the average bed elevation. Average flow velocity (U) was estimated by averaging ADV measurements throughout each run. Slope is the average of measured waterslopes during each run. Froude (Fr) and Reynolds (Re) numbers are estimated using flow depth and velocity and standard values for water density and viscosity. Baas et al. experiments include those that match the experimental conditions of this study most closely. Baas et al. classify the flow structure of their runs using detailed Ultrasonic Doppler velocimetry profiling (listed in Notes column). All data were reported in their 2009 and 2011 papers; slope value for the 2011 run is a bed slope. For Packman and MacKay experiments, slope is reported as "energy grade line"; Fr and Re were not reported in their paper, so we estimated values for each run (italics).

\begin{tabular}{|c|c|c|c|c|c|c|c|c|}
\hline & Run & $\mathrm{C}(\mathrm{mg} / \mathrm{l})$ & $\begin{array}{c}\text { h } \\
(\mathrm{cm})\end{array}$ & $\begin{array}{c}\mathrm{U} \\
(\mathrm{cm} / \mathrm{s})\end{array}$ & Slope & Fr & $\mathbf{R e}$ & Notes \\
\hline \multirow{5}{*}{$\begin{array}{l}\text { Wysocki \& } \\
\text { Hajek (this } \\
\text { study) }\end{array}$} & $\begin{array}{l}\text { No Fines } \\
\text { (control) }\end{array}$ & 0 & 17.5 & 45 & 0.0018 & 0.34 & 78750 & \multirow{5}{*}{$\begin{array}{l}\text { Variable Flow } \\
\text { Run values are for } \\
\text { high flow } \\
\text { conditions }\end{array}$} \\
\hline & $\begin{array}{l}\text { Low } \\
\text { Conc. }\end{array}$ & 1000 & 16.6 & 50 & 0.0019 & 0.39 & & \\
\hline & $\begin{array}{l}\text { Intermed. } \\
\text { Conc. }\end{array}$ & 4000 & 15.1 & 40 & 0.0016 & 0.33 & 60400 & \\
\hline & $\begin{array}{l}\text { High } \\
\text { Conc. }\end{array}$ & 8500 & 14.9 & 60 & 0.0019 & 0.50 & 89400 & \\
\hline & $\begin{array}{c}\text { Variable } \\
\text { Flow }\end{array}$ & 1000 & 16.2 & 46 & 0.0020 & 0.37 & 74520 & \\
\hline \multirow[t]{3}{*}{$\begin{array}{l}\text { Baas et al. } \\
\text { (2011) }\end{array}$} & 1 & 5200 & 15.1 & 46.5 & 0.00138 & 0.38 & 69939 & Turbulent Flow \\
\hline & $3-1$ & 500 & 14.5 & 43.9 & 0.00018 & 0.37 & 63599 & Turbulent Flow \\
\hline & $3-2$ & 4000 & 15.7 & 42.6 & 0.00029 & 0.34 & 65256 & Turbulent Flow \\
\hline \multirow[t]{4}{*}{$\begin{array}{c}\text { Baas et al. } \\
\text { (2009) }\end{array}$} & $3-3$ & 9600 & 15.5 & 41.4 & 0.00029 & 0.34 & 63473 & $\begin{array}{c}\text { Enhanced } \\
\text { Transitional Flow }\end{array}$ \\
\hline & $4-2$ & 4000 & 15.4 & 55.9 & 0.00029 & 0.44 & 86023 & Turbulent Flow \\
\hline & $4-3$ & 9800 & 15.1 & 55.7 & 0.00029 & 0.43 & 83182 & Turbulent Flow \\
\hline & $5-2$ & 4200 & 15.0 & 70.4 & 0.00029 & 0.58 & 105467 & Turbulent Flow \\
\hline \multirow{3}{*}{$\begin{array}{c}\text { Packman } \\
\text { and MacKay } \\
(2003)\end{array}$} & 1 & $\begin{array}{c}230,460, \\
230\end{array}$ & 8.7 & 23.3 & 0.064 & 0.25 & 20271 & \multirow{3}{*}{$\begin{array}{c}\text { Pulsed injections } \\
\text { of clay } \\
\text { Pulsed injections } \\
\text { of clay } \\
\text { Pulsed injection } \\
\text { of clay }\end{array}$} \\
\hline & 2 & $\begin{array}{c}280,230 \\
220\end{array}$ & 11.8 & 23.7 & 0.044 & 0.22 & 27966 & \\
\hline & 3 & 810 & 8.6 & 23.6 & 0.064 & 0.26 & 20296 & \\
\hline
\end{tabular}


Figure DR4: Comparison of flow conditions in experiments from this study to the phase diagram presented in Baas et al. (2009).

Approximate range of experiments in this study shown in the gray box. Note that their diagram is for flow depths from $0.13-0.16 \mathrm{~m}$, and that some of our experiments are slightly above those depths. Baas et al. Figure 17.

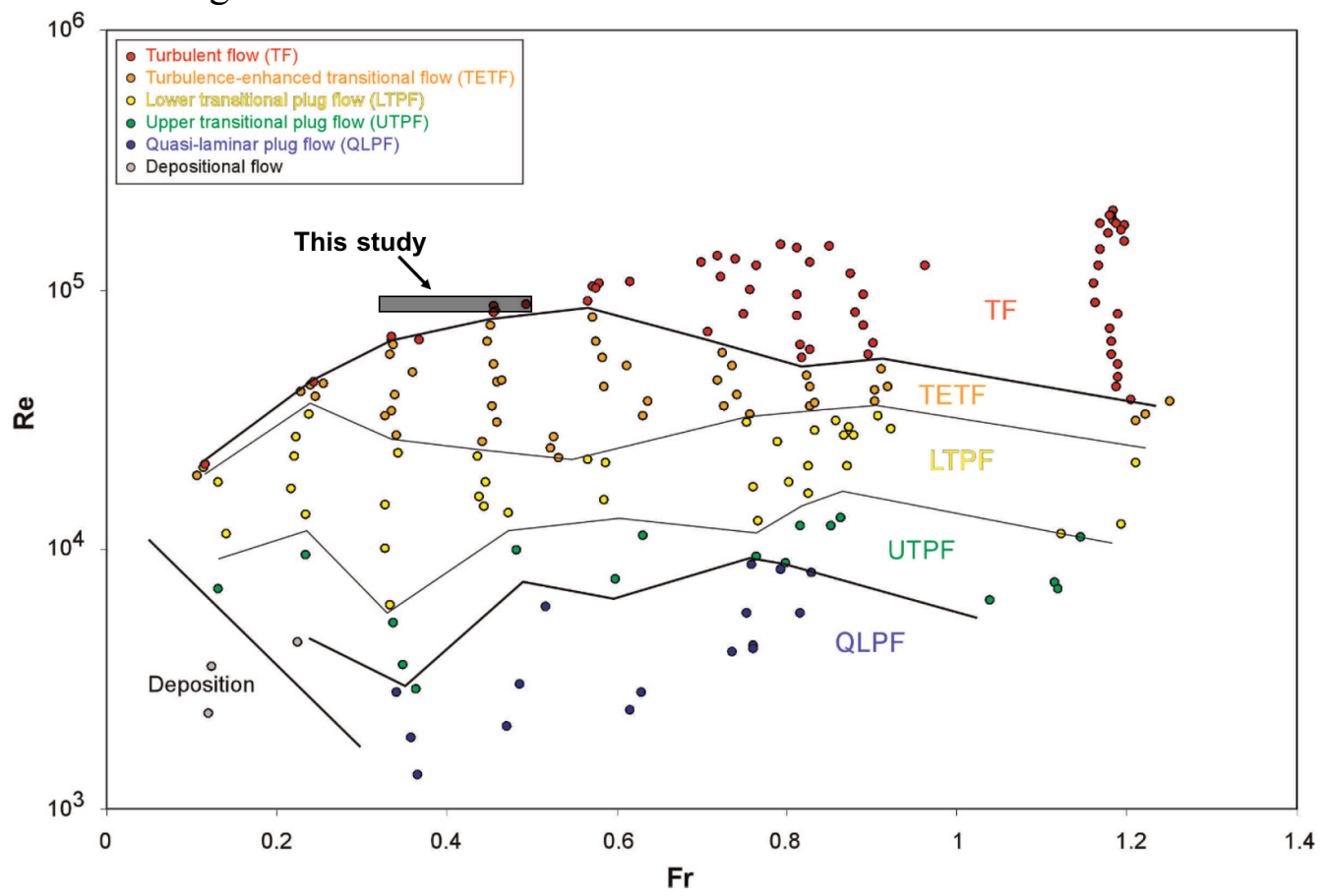

Figure DR5: Comparison of experiments in this study to the clay flow phase diagram of Baas et al. (2009).

Approximate range of experiments in this study is shown in the orange box. $U$ is the depthaveraged flow velocity and $\mathrm{C}$ is the depth-average volume concentration of clay. Baas et al. Fig $15 \mathrm{~A}$.

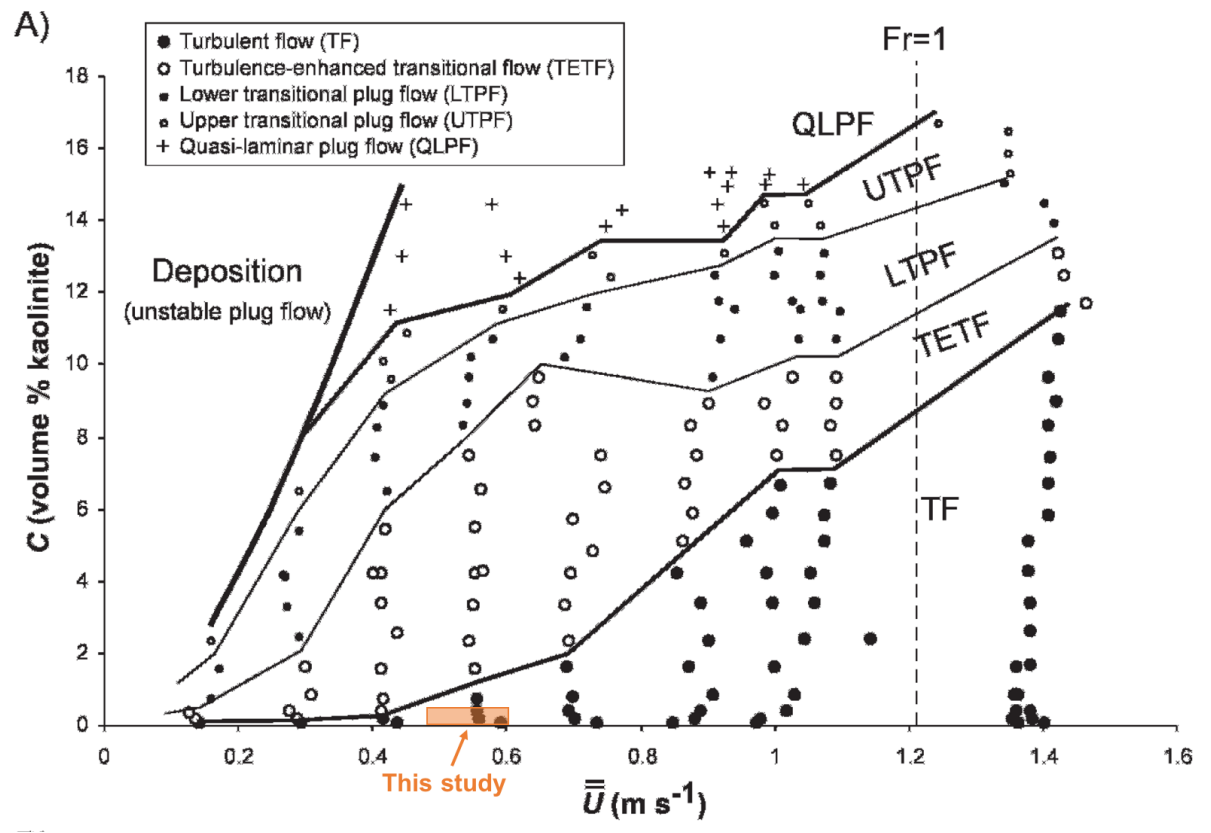


Figure DR6: Topographic profiles through time of each experiment.

The top figure in each set is the measured values and the bottom figure is smoothed profiles, which is accomplished with a moving window two average dune lengths $(50 \mathrm{~cm})$; colors show profiles every 30 minutes (light to dark, as in Manuscript Figure 1). Vertical exaggeration is 3x.

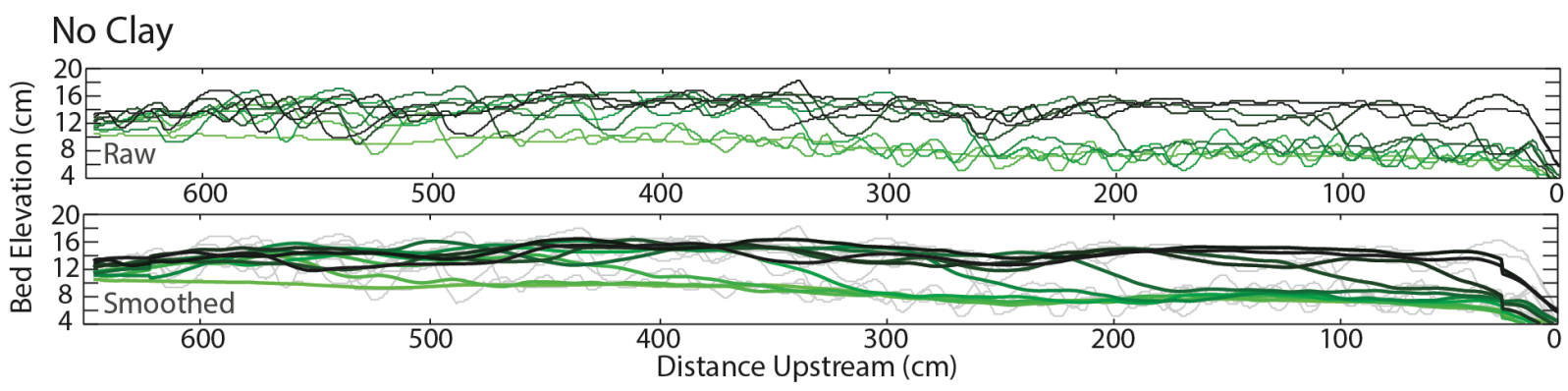

High Concentration

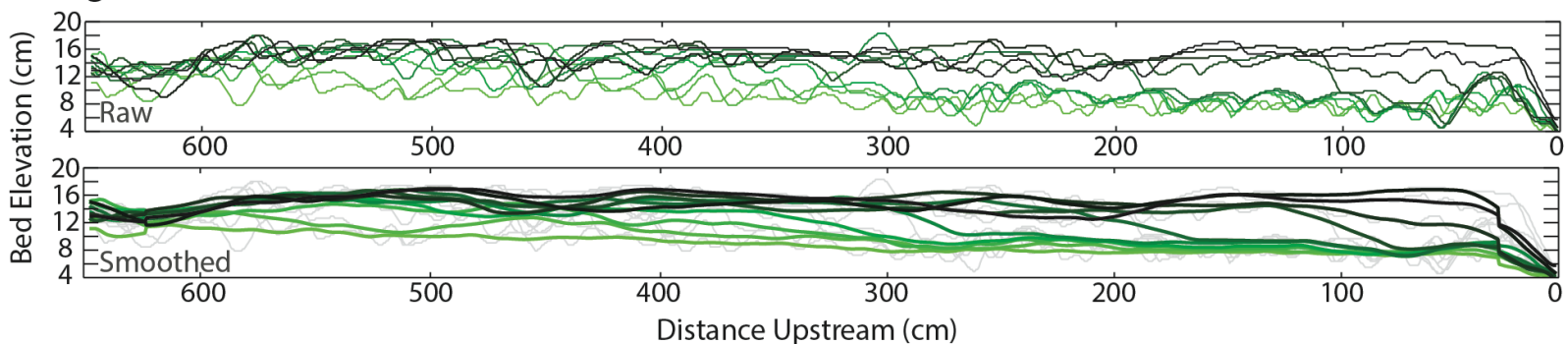

Intermediate Concentration

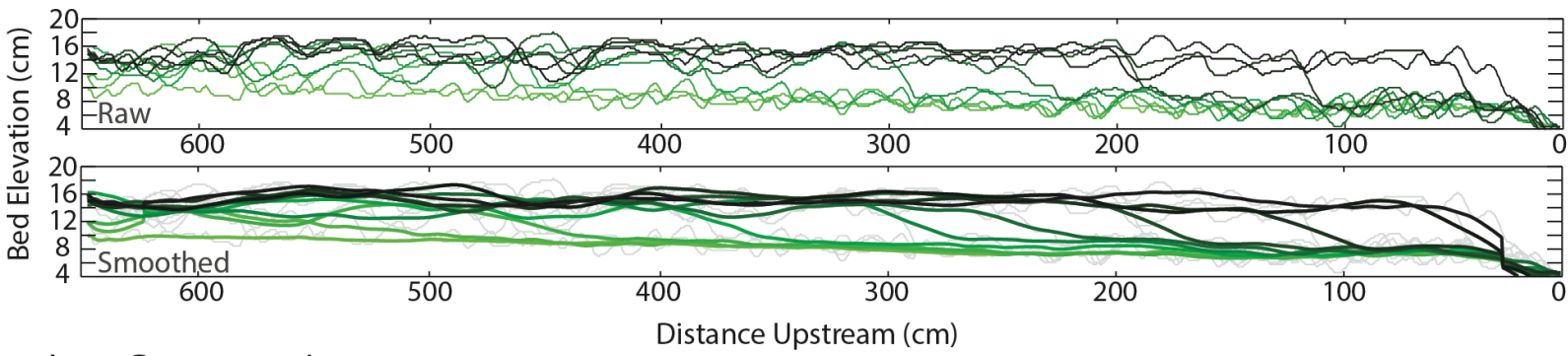

\section{Low Concentration}

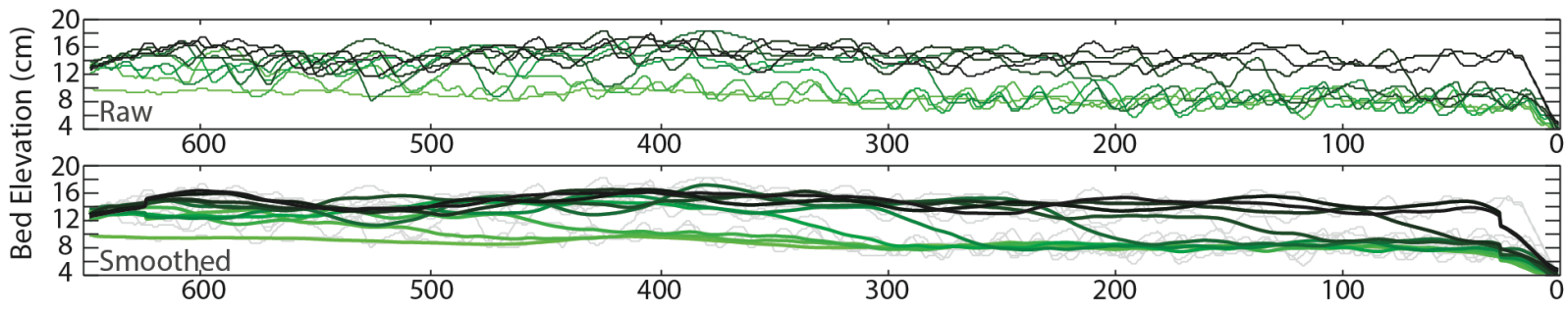

Variable Flow

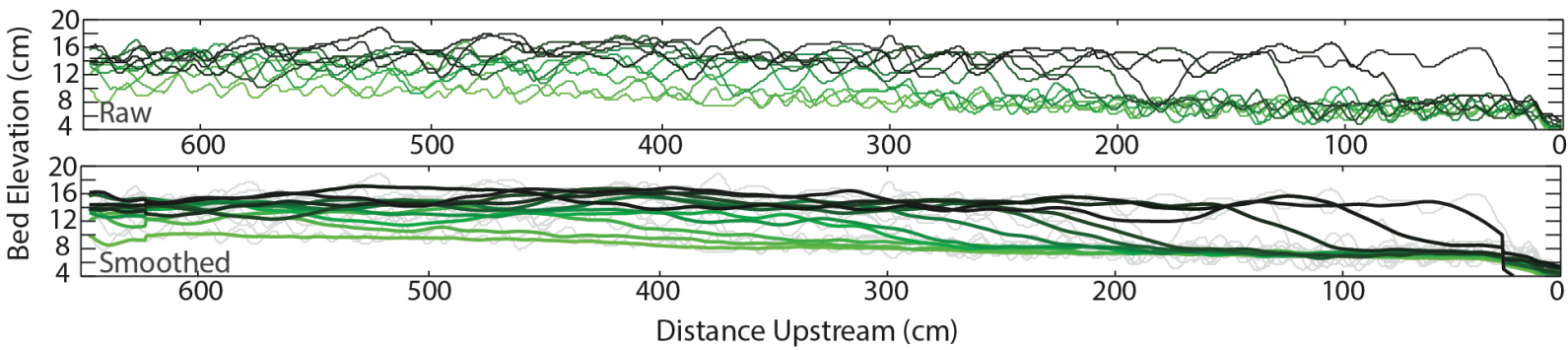


Figure DR7: Turbulence intensity calculated from ADV data from each run.

There is no evidence of damping of turbulence at high clay concentration.

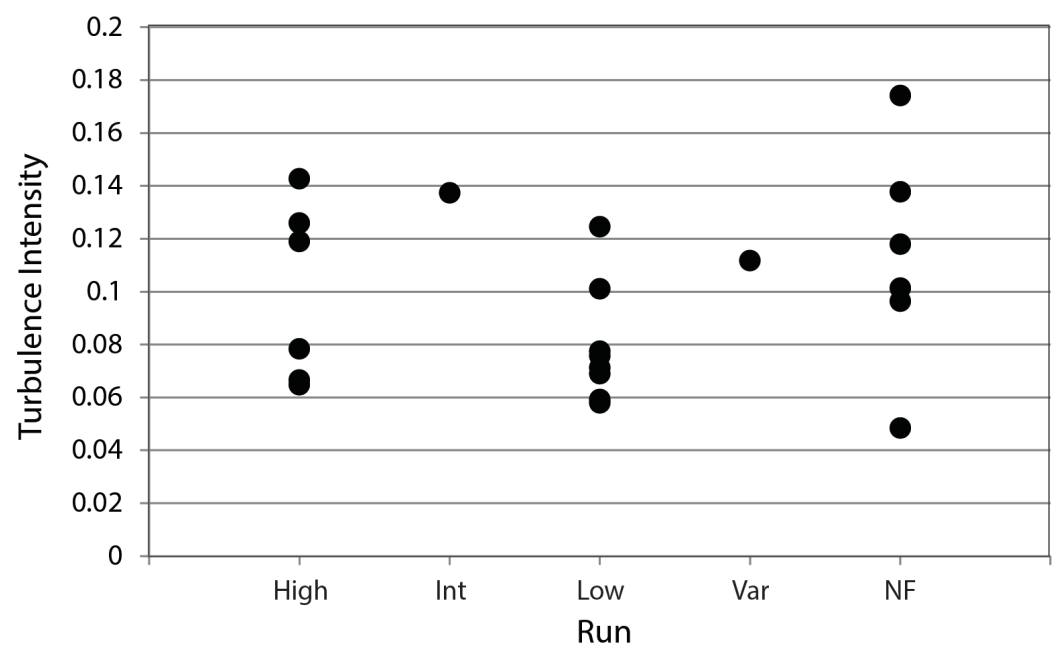

WinADV was used to process ADV data. Data were filtered using the automatic despiking program and used to calculate Turbulence Intensity (TI):

Turbulence intensity (TI)

$$
T I=\frac{u^{\prime}}{U}=\frac{\sqrt{\frac{1}{3}\left(u_{x}^{\prime 2}+u_{y}^{\prime 2}+u_{z}^{\prime 2}\right)}}{\sqrt{U_{x}^{2}+U_{y}^{2}+U_{z}^{2}}}
$$

where $u^{\prime}$ is the root mean square of the turbulent velocity fluctuations and $U$ is the mean velocity. 
Figure DR8: Suspended sediment concentration profiles.

Experiments show a generally well-mixed clay concentration throughout the water column. Clay concentration varies during a run, but there was no overlap in clay concentration between runs.

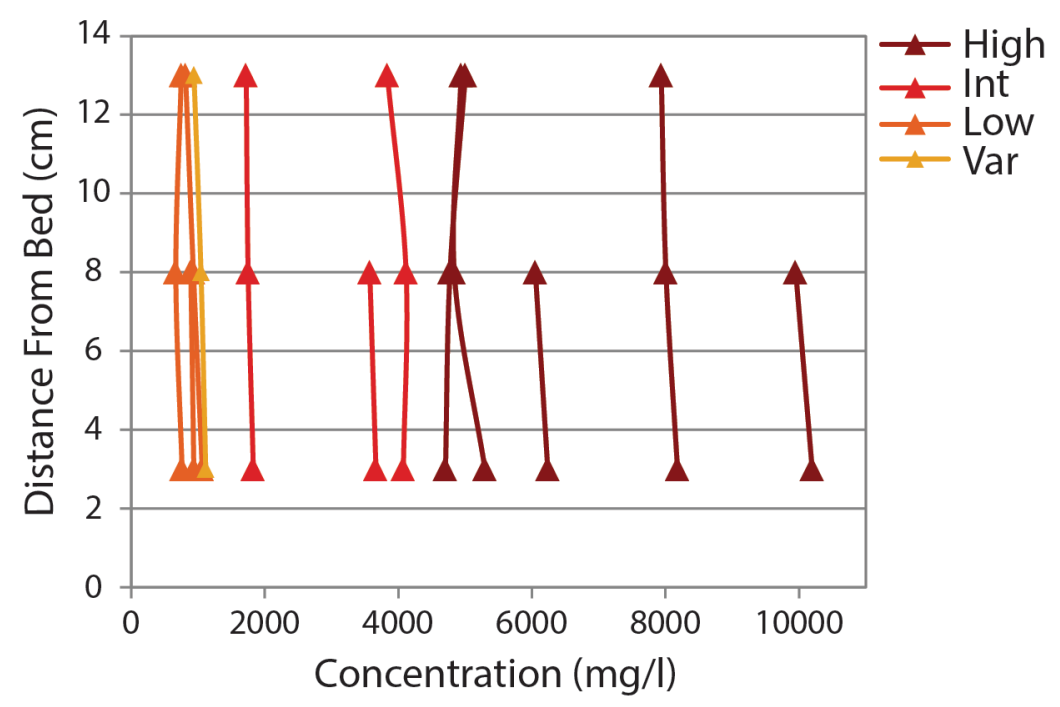

Figure DR9: Example images of clay aggregates in experimental runs.

Kaolinite flocs (white dots) in both the low-concentration run (A) and in the high-concentration run (B). Along the flume wall, in videos, there was evidence of flocculation in all runs, with more in the high-concentration experiment. However, clay flocculation was not did not occur at a level that changed the overall concentration of clay recorded in each experiment (Figure DR8), so it was not the dominant mode of clay transport in any of the runs. This is consistent with flocculation conditions documented in other experiments, where the conditions in this study (freshwater with clay concentrations $<0.5 \mathrm{wt} \%$ ) are below reported thresholds for significant flocculation (e.g., > $3.0 \mathrm{wt} \%$ in fresh water in Sutherland et al. (2015))
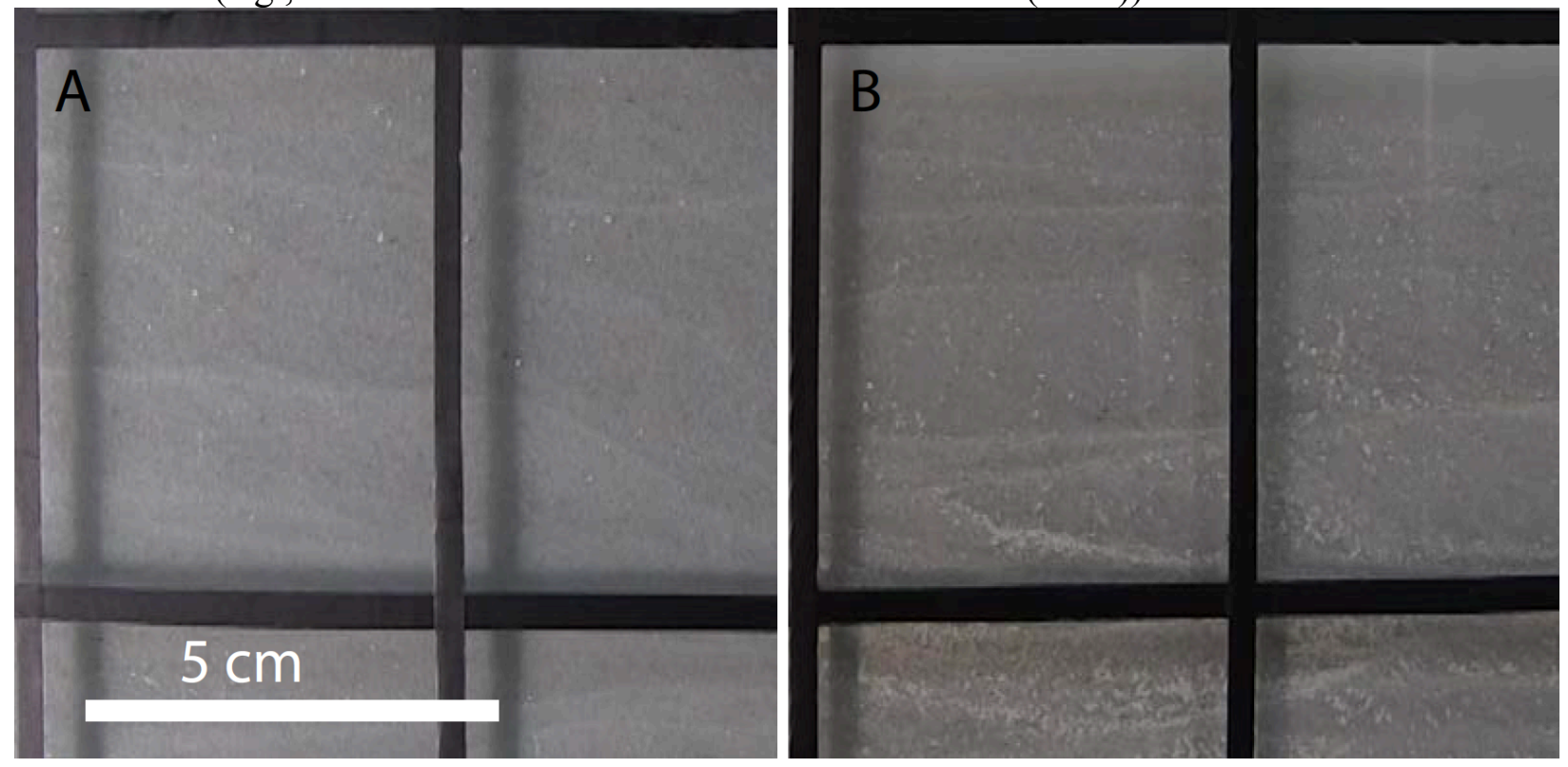


\section{DEPOSIT CHARACTERISTICS AND CLAY ACCUMULATIONS:}

Table DR4: Experimental deposit characteristics and clay-mapping results.

\begin{tabular}{|c|c|c|c|c|c|}
\hline Run description & No Fines & $\begin{array}{c}\text { Low } \\
\text { Concentration } \\
\end{array}$ & $\begin{array}{c}\text { Intermediate } \\
\text { Concentration } \\
\end{array}$ & $\begin{array}{c}\text { High } \\
\text { Concentration } \\
\end{array}$ & $\begin{array}{c}\text { Variable } \\
\text { Discharge }\end{array}$ \\
\hline \multicolumn{6}{|c|}{ GENERAL DEPOSIT CHARACTERISTICS } \\
\hline $\begin{array}{l}\text { Aggradation phase } \\
\text { deposit thickness (cm) }\end{array}$ & 4.3 & 4.2 & 4.6 & 5.1 & 5.0 \\
\hline $\begin{array}{l}\text { Bypass phase deposit } \\
\text { thickness }(\mathrm{cm})\end{array}$ & 3.0 & 2.6 & 3.5 & 3.0 & 3.2 \\
\hline $\begin{array}{l}\text { Total deposit cross- } \\
\text { sectional area }\left(\mathrm{cm}^{2}\right)\end{array}$ & 4313 & 4533 & 4627 & 4737 & 5230 \\
\hline $\begin{array}{l}\text { Aggradation phase } \\
\text { deposit cross-sectional } \\
\text { area }\left(\mathrm{cm}^{2}\right)\end{array}$ & 2549 & 2554 & 2596 & 3022 & 3250 \\
\hline $\begin{array}{l}\text { Bypass phase deposit } \\
\text { cross-sectional area } \\
\left(\mathrm{cm}^{2}\right)\end{array}$ & 1765 & 1976 & 2032 & 1664 & 2010 \\
\hline $\begin{array}{l}\text { Fraction of total } \\
\text { deposit formed during } \\
\text { aggradational phase }\end{array}$ & 0.59 & 0.56 & 0.56 & 0.64 & 0.62 \\
\hline \multicolumn{6}{|c|}{ CLAY ACCUMULATIONS } \\
\hline $\begin{array}{l}\text { Types of clay } \\
\text { accumulations }\end{array}$ & None & $\begin{array}{l}\text { None (small } \\
\text { drapes near weir } \\
\text { downstream of } \\
\text { test section) }\end{array}$ & $\begin{array}{l}\text { Continuous clay } \\
\text { drapes, abundant } \\
\text { intercalated clay }\end{array}$ & $\begin{array}{l}\text { Continuous clay } \\
\text { drapes, clay-rich } \\
\text { lenses, abundant } \\
\text { intercalated clay }\end{array}$ & $\begin{array}{l}\text { Discontinuous } \\
\text { clay drapes }\end{array}$ \\
\hline \multicolumn{6}{|c|}{ Percent of total run deposit } \\
\hline Intercalated clay & N/A & 0 & 34 & 40 & 0 \\
\hline Drapes & N/A & 0.1 & 8 & 12 & 1 \\
\hline Clay rich lenses & N/A & 0 & 0 & 6 & 0 \\
\hline \multicolumn{6}{|c|}{ Percent of aggradation phase deposit } \\
\hline Intercalated clay (\%) & N/A & 0 & 61 & 62 & 0 \\
\hline Drapes (\%) & $\mathrm{N} / \mathrm{A}$ & 0.1 & 14 & 19 & 1 \\
\hline Clay rich lenses $(\%)$ & N/A & 0 & 0 & 10 & 0 \\
\hline
\end{tabular}




\section{BED DEPOSIT SAMPLING}

After each experiment, the bed was slowly drained and allowed to dry for two days prior to excavation. At this point the bed was dry enough to excavate without significantly collapsing. Bed-deposit samples and photographs were taken from the middle of the flume at various locations at different depths (Table 3 ) in order to capture samples deposited during both bypass and aggradation phases. These samples were taken with a $7 \mathrm{~cm} \times 7 \mathrm{~cm}$ excavator tool, which allowed for bulk sediment samples. Bed-deposit samples were then wet-sieved to determine the fraction of clay.

Table DR5: Bed-deposit sample locations and weight percent of clay in the sample.

Depositional phase and type of clay accumulations captured by each sample are noted. Qualitative sample descriptions describe the nature sample after being oven dried. Sands in some samples were clumped together and had to be manually disaggregated after sampling, indicating abundant clay. The NF run was a control experiment conducted with no clay discharge. Claysized material detected in that run came from the water (supplied from the Mississippi River via the St. Anthony Falls Lab main-channel diversion) or residuum within the sand supply.

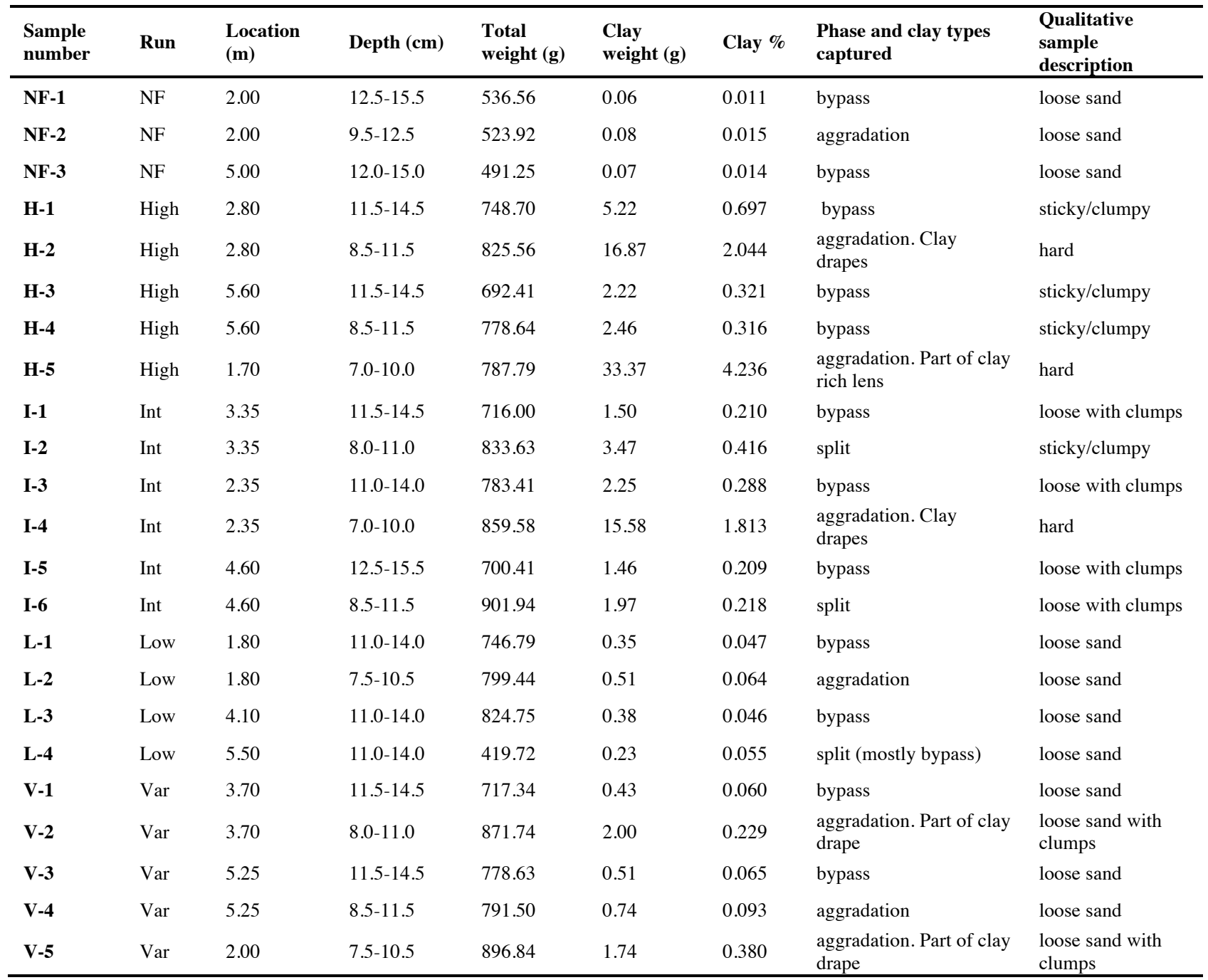




\section{Bed Deposit Mapping Description and Images}

Clay accumulations and bed areas are mapped on the vertically exaggerated images. Overlain topographic profiles and bed elevation points taken during the run helped determine which sediment was deposited during the bypass vs. aggradation phase. Clay accumulations were mapped on photographs of the bed. Clay accumulations appear whiter than the background sand, which is a tan color. Lighter colored sand indicates a higher abundance of intercalated clay (verified with weight percents of individual samples from these regions). Long and thin accumulations of clay were mapped as drapes and larger, thicker deposits were mapped as clay lenses. Bed areas of each type of clay accumulation were quantified using image analysis tools in Matlab.

\section{Figure DR10: Photographs and mapped clay accumulations of each run as seen through the glass wall of the flume.}

(Next pages) Vertical exaggeration is $3 x$. The $y$-axis is depth in centimeters. Hatched area is prerun sediment. White areas are obstructed views of the bed. Sample locations are noted by black boxes. Each experiment (A-D) includes the following: i) composite photograph of test section through glass panel, ii) map of clay accumulations preserved in the bed (black) and definition of aggradational phase area (dark gray) and bypass phase area (light gray), and iii) map of different types of clay accumulations observable in the bed including, intercalated clay (dark gray), clay drapes (black), and clay rich lenses (red). 


\section{A. High Concentration Run}
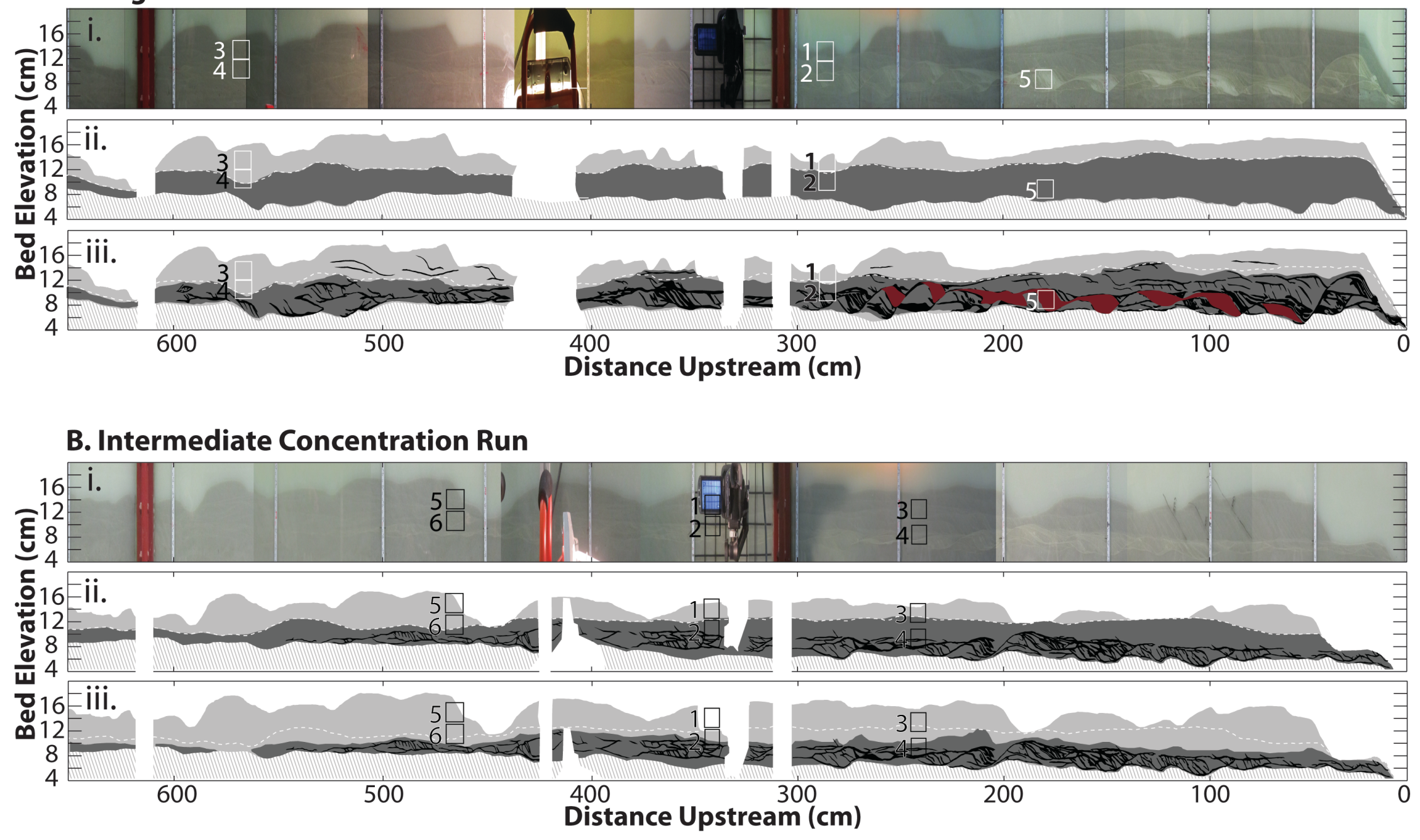


\section{Low Concentration Run}

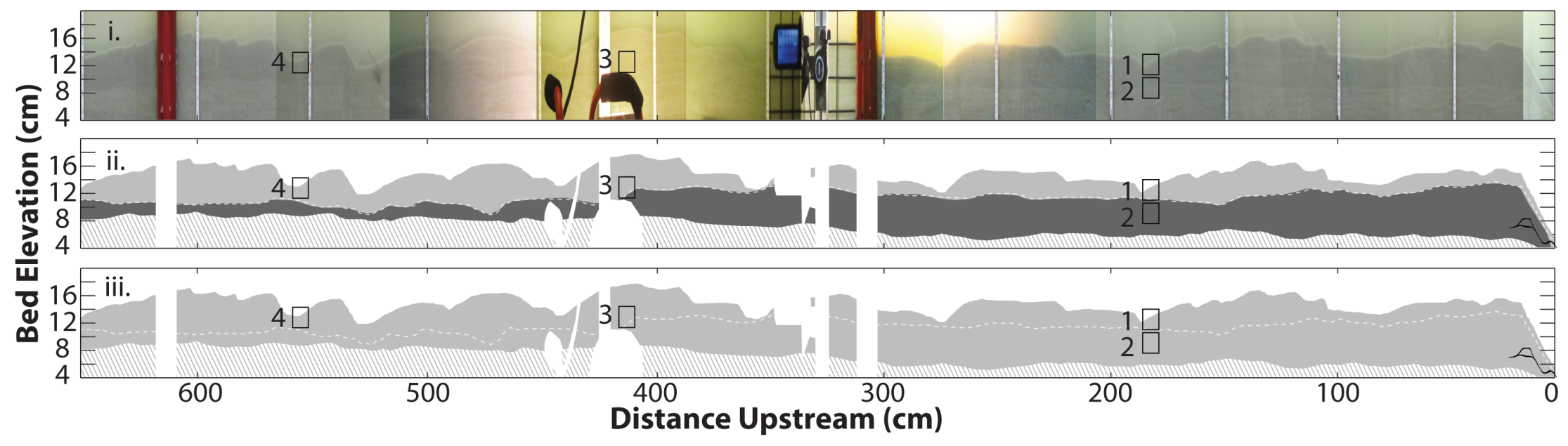

\section{Variable Discharge Run}

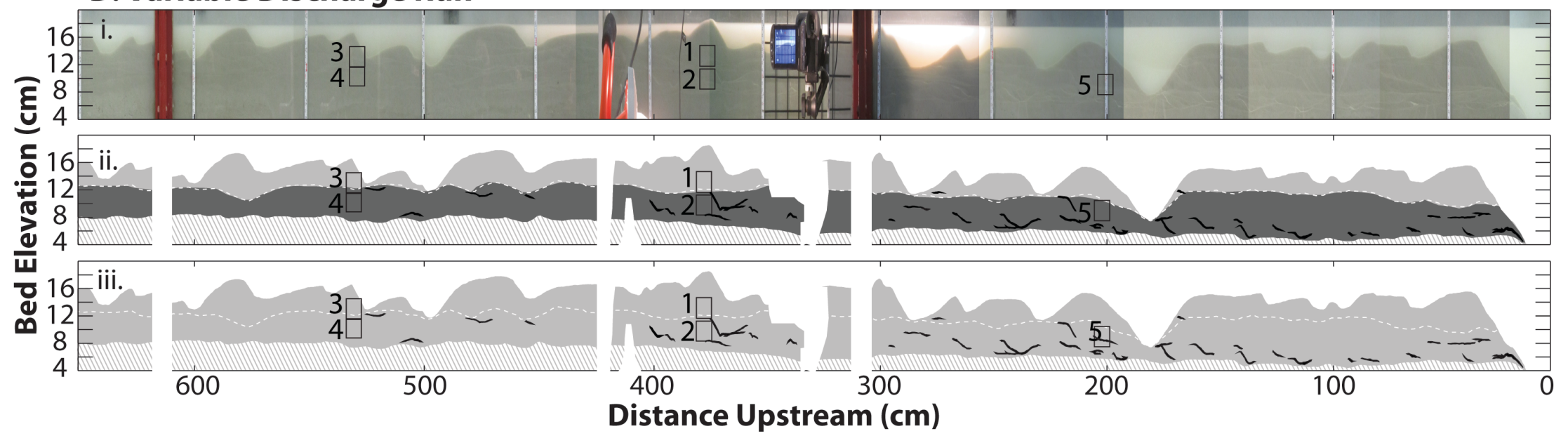




\section{REFERENCES}

Baas, J. H., Best, J. L., and Peakall, J., 2011, Depositional processes, bedform development and hybrid bed formation in rapidly decelerated cohesive (mud-sand) sediment flows: Sedimentology, v. 58, p. 1953-1987.

Baas, J. H., Best, J. L., Peakall, J., and Wang, M., 2009, A phase diagram for turbulent, transitional, and laminar clay suspension flows: Journal of Sedimentary Research, v. 79, p. 162-183.

Packman, A. I., and MacKay, J. S., 2003, Interplay of stream-subsurface exchange, clay particle deposition, and streambed evolution: Water Resources Research, v. 39, no. 4.

Sutherland, B. R., Barrett, K. J., and Gingras, M. K., 2015, Clay settling in fresh and salt water: Environmental Fluid Mechanics, v. 15, no. 1, p. 147-160.

Wilkerson, G. V., and Parker, G., 2011, Physical basis for quasi-universal relationships describing bankfull hydraulic geometry of sand-bed rivers: Journal of Hydraulic Engineering, v. 137, no. 7, p. 739-753. 